\title{
Dialectic Approaches and Public Policy Interactions for Social, Environmental and Health Problems: Challenges for Health Promotion across Territorial Scales
}

\author{
Leandro Luiz Giatti', Ricardo Agum Ribeiro'2, Renata Ferraz de Toledo ${ }^{3}$ \\ ${ }^{1}$ Faculdade de Saúde Pública, Universidade de São Paulo, São Paulo, Brazil \\ ${ }^{2}$ Programa de Pós-Graduação em Ciência Política, Instituto de Ciências Humanas e Filosofia, Universidade \\ Federal Fluminense, Niterói, Brazil \\ ${ }^{3}$ Faculdade de Educação, Universidade de São Paulo, São Paulo, Brazil \\ Email: Igiatti@usp.br
}

Received 23 January 2014; revised 28 February 2014; accepted 8 March 2014

Copyright (C) 2014 by authors and Scientific Research Publishing Inc.

This work is licensed under the Creative Commons Attribution International License (CC BY).

http://creativecommons.org/licenses/by/4.0/

(c) (i) Open Access

\begin{abstract}
A constant reproduction of environmental injustices and health iniquities has demanded the employment of participatory/dialectic approaches to research and to intervene in the reality making possible the involvement of social actors in healthy public policies. On this framework, the aim of this paper is to analyse scientific production with dialectic approaches associated with public policies in the context of social, environmental and health problems, considering territorial scales of intervention and the correspondence with some relevant strategies of health promotion. A systematic bibliographic review was applied on a wide pan-disciplinary scientific data base and 36 papers were analysed and classified by their territorial scales of approach. The amount of papers found and their spread through a variety of journals showed a modest, but increasing production which has been dispersed in terms of knowledge areas. Within the classification of territorial approaches, 14 papers were classified as local, 5 as expanded and 17 as a multi-level. Although the papers classified as local approaches were in a good structure of stakeholders' participation, they are limited to dealing with the global driving forces that reproduce the environmental injustices. Regarding this limitation, the multilevel approaches were identified as more opportune to jointly deal with social, environmental and health problems by means of allowing interaction through multiple territorial scales, fomenting the strengthening of community action, creating supportive environments, and building healthy public policies.
\end{abstract}

\section{Keywords}

Health Promotion; Participatory Research; Public Policy; Environmental Justice 


\section{Introduction}

The recognition of social and environmental determinants of health has driven to the need for a multidisciplinary and cross-territorial framework to search for equity once the economic development lead by global forces induces a constant reproduction of social exclusion, environmental degradation and the overlap of a variety of risk factors over human populations. The context in which certain social groups are unequally exposed to the worse combined situations of social and environmental factors can be named environmental injustice [1], and its driving forces associated to the worldwide dissemination of critical scenarios in this context are the fluidity of the circulation of international capital associated with its capability to counteract local governance searching for effectiveness and profit beyond national boundaries, optimizing human, economic and environmental resources [2].

On such background the concept of health promotion can be emphasized because it reinforces that the health policy priorities must be reoriented from a risk factor approach to strategies that can address the determinants of health, as well as the need for empowering people within participatory processes, aiming at improving health of communities in a new public health practice. In this paper, this amount of characteristics is considered as a dialectic ${ }^{1}$ approach. Under the health promotion assumptions health is viewed as a resource that is created in everyday life, by joining efforts from government and the society together [3] [4].

The promotion of dialectic processes linking scientific and popular knowledge has been considered fundamental in academic movements and initiatives which aims at intervening in real situations associated with social, environmental and health questions. Post-normal science [7] [8] argues for the need of extended peer communities, the whole society, to be involved in the production of knowledge and the management of uncertainties that offer high degree of risk. This is also the case with the ecosystem approach to health, known as Ecohealth, based on the pillars of transdisciplinarity, participation and equity, where the aim of participation is to foster cooperation and reach consensus, not only within the local community and amongst scientific researchers and decisionmakers, but also among these different social actors [9]. Also, we can consider the relevance of the Community Based Participatory Research-CBPR — which claims that participants must be involved in the search for solutions to specific interdisciplinary problems; and so research is developed by constantly reflecting on action and promoting collective learning [10]-[12].

The roots of participatory or dialectic approaches to deal with inequities were disseminated since the 1940's and the 1970's respectively by Kurt Lewin and Paulo Freire. Firstly, Lewin worked with an action research combining interactive methods in a cyclic process of planning, acting and fact finding, involving minority groups under social exclusion improving self-esteem, equality and co-operation [10] [13]. Freire made a very relevant contribution to education of oppressed people and his postulates enhanced the common sense putting it as necessary to be part in the education as well as in the research contexts. Within a liberating practise the propositions of Freire strengthens a dialectic to build new knowledge and collective learning, fighting against social exclusion and oppression while making it possible to value different knowledge to understand and to deal with local problems [6]. Both Lewin's and Freire's assumptions can be considered as basic for the empowerment of communities under pressure of the environmental injustice that can exacerbate risks to collective health.

But coming from an academic initiative trying to combine different kinds of knowledge as scientific and popular, empowering people with participatory approaches and creating new and hybrid knowledge does not necessarily mean to make or to interact with public policy. Actually, there are other aspects inherent of policymaking which can be decisive to induce the priorities in the policy agenda as well as in the governmental actions [14]. In addition, considering that the main driving forces of environmental injustices are caused by the fluidity of the capital, even reaching the best quality of dialectic processes, when a local community is enabled with autonomy and proactive stance [15], the cross territorial reproduction of social exclusion and environmental degradation still lead to critical scenarios posing challenges for public health. In other words, acting local cannot be enough to cope with a dynamic that comes from a global process.

\footnotetext{
${ }^{1}$ We assume that the dialectic process is an interactive approach, although there are a variety of understandings for the term dialectic. In our assumption there is an intent of proving a thesis by means of arguments which are formatted in contradiction. In such reflexion the tools of intervention in the reality can be viewed as better elaborated than the simple interpretation. Hegel and Marx [5] showed that the dialectic method can explain the reality through confrontation of oppositions, thus rejecting appearances imposed by the status quo and believing in the ongoing change of what we consider reality. Freire [6] applied this concept of dialectic to education and research emphasizing the importance of different—and frequently marginalized—knowledge to understand and interact in the reality, to result in more symmetrical social relations.
} 
Hancock (2011) [16] and Kickbusch (2007) [17] emphasize that the principles of the Ottawa Charter for health promotion are very important challenges not only for the current, but especially for the future generations of public health professionals and policy makers. In this sense, the component of the socio-ecological approach to health from the Ottawa Charter $[3]^{2}$ is treated in this text as the necessary empowerment and participatory initiatives within contexts of socio, environmental and health problems, also considering an imperative link with public policies. Indeed, the sum of these characteristics constitutes a complex configuration with limitations for the scientific, communitarian and governmental capabilities, being also important to promote interaction among those social groups [8]. Two questions arise under these considerations: How has been the development of scientific production dealing with participatory/dialectic research associated with public policies in the intersection of social, environmental and health problems? How does the related situations described by this specific scientific production deal with the global-local forces that reproduces the worse scenarios of environmental injustices?

Through a systematic bibliographic review, the objective of this paper is to analyse scientific production dealing with dialectic approaches associated with public policy in the context of social, environmental and health problems, considering territorial scales of intervention and verifying how to combine three important strategies of health promotion from the Ottawa Charter [3] which are: strengthening of community action, creating supportive environments, and building healthy public policies.

\section{Methodological Remarks}

The systematic bibliographic review [18] started with a search for papers in the Thompson Reuters' Web of Science. This source was chosen because of its general recognition as a pan-disciplinary bibliographic database [19]. The keywords applied for the search in topics were: "health" and "environment" or "environmental" plus "participation" or "participatory" or "post-normal" or "governance" or "ecohealth". The time span for the search was from 1864 to 2012. Although the year 1864 was allowed because of the availability of the database, the oldest paper selected dated from 1999.

The first relation of papers found by key words brought 1.212 papers; they were subsequently filtered in a process with a careful reading of the abstracts. At this phase 3 refining criteria were applied according to the adopted conditions for inclusion of papers as follows: 1) being related to a participative research or a participatory/dialectic intervention process dealing with social, environmental and health questions and being even related to different geographic scales of intervention, such as local, communitarian, urban, territorial or national; 2) relating to a dialectic process within certain public policy or involving social actors through dialectic tools for participatory processes, not only with the purpose of acquiring information, but bringing them together in the application of research tools, discussion of outcomes, planning research or interactive activities [12]; 3) being the participatory/dialectic process associated to any public policy—this last inclusion criteria was also the last phase of paper selecting.

Some exclusion criteria were also adopted as follows: papers based upon reviews which did not bring any kind of practical experience or empirical descriptive data; some not presenting clear indication of participatory approaches or tools with a dialectic involvement of social actors; some pointing out participatory or dialectic approaches just as conclusion or recommendation.

After the application of the cited refining criteria and a search for full papers 36 texts were analyzed under aspects associated with the objectives enlightening how educational and health promotion aspects can be identified in association with participatory/dialectic approaches and public policy concerning social, environmental and health problems within different territorial scales of intervention. With regard to the territorial scales of intervention, there is a key concern under the global-local relationships. The following three categories were employed: a) local-targeting a community or a specific group of social actors with a singular characteristic, not expanding the approach to a wider territorial range; b) expanded scale — could be in the territory of a city or a municipality, a country or even global, this category was also connected with the challenge of a participatory process with necessary representation of the population of the territories; and c) multi-level—when the participatory process occurred for example from a local intervention to bring new arrangements in a situation related to

${ }^{2}$ The Ottawa Charter was the product of the first international conference on health promotion held in Canada, 1986, under the leadership of the World Health Organization. The importance of this document is seminal to overcome a model of individualistic risk factors and risk behaviors for health care and attention shifting to a new paradigm of context and meaning of health actions and the determinants that keep people healthy [4]. 
the territory or even to the global scale, also considering when the reported approach integrated an initiative from a wider territorial range unfolding in interventions towards small scales.

\section{Analysis of the Bibliographic Evidences}

The last phase of paper selecting brought a clue to the importance of verifying the relation of dialectic approaches with public policy because under this condition the 36 selected papers represented $21 \%$ of the 170 papers that fulfilled the conditions of being related to a participative research or a participatory/dialectic intervention process dealing with social, environmental and health questions through different geographical scales. It reinforces that academic criticism and initiative towards participatory approaches can occur separately from the public policies. Kingdon (2003) [20] launches this questioning whether the participatory approach induces the policy agenda or the policy agenda demands the elaboration of participatory tools. Actually, the author emphasizes that the policy agendas suffer constant pressure and control by the dominant power.

When we analyze the participation of social actors in a dialectic way within public policies involving means of valuing different knowledge and empowering communities to take part in the processes, we are looking at the inherent contradiction at the same time as we reflect about the opposition of the established power. On the other hand, we can argue that meanwhile there is a recommendation for more participation of social actors in healthy policies [3], the related scientific production seems to be very modest as we assess in the framework of this paper, even though there is a growing trend of production in the recent years. For our scope of study the first paper found was published in 1999, being the only one found in this year. In 2000 we found 4 papers. In the following 6 years (2001-2006) 14 papers and in the last span of 6 years (2007-2012) 17 papers.

Although the selection criteria allowed finding papers with the similarities required for our concerns it is possible to state that there is no specific publishing space for the 36 included papers that were published among 32 different journals (Table 1). Only 4 journals presented 2 selected papers and although there is a strong representation of health related journals, we can consider that the scientific production about our concern is disperse.

In Table 2 we expose examples of how the dialectic approaches were considered by means of interaction with public policies. The dialectic approaches could be associated with a participatory research involving community actors or even by means of the interaction among different territorial levels of a certain policy, indicating the necessary involvement of different social actors. The relation with public policy can be observed when it induces a dialectic approach or when a participatory/dialectic approach aims at bringing the social actors to interact with the public policies. With the presented examples we hope to offer a variety of situations of dialectic methods as well as public policy relation, also showing situations across diverse territorial scales.

In a joint examination of the five examples of the Table 2 we realize that the dialectic approach operates in an intrinsic way with the complexity of the socio environmental and health context under study and intervention. If on one hand we have a participatory approach that promotes involvement of local community actors revealing risk factors not evident before, improving a public policy within its actions through a bottom-up intervention, like Lazenbatt et al., 2001 [22] shows, on the other hand we determine that in a cross territorial policy it is imperative that a dialectic process be operated to warrant the sustainability of a top-down initiative to be successfully applied within a small scale context [23] [25].

Following the analysis of similarities of dialectic process through different territorial scales we present Table 3 with the classification of papers by local, expanded and multilevel scales of intervention. The local approaches can be characterized by initiatives of research and intervention addressed at small villages, or social groups un-

Table 1. Journals of publication of the selected papers in alphabetical order/number of published papers in each journal.

Environment and Urbanization/1-American Journal of Community Psychology/1—American Journal of Preventive Medicine-/1— American Journal of Public Health/2_Ecological Economics/1_Electronic Government/1—Environment and Planning B: Planning and Design/2_Environment and Urbanization/1_Environmental Health Perspectives/1—Environmental Policy and Governance/1—Futures/ 1-Health Education \& Behavior/2 - Health Education Research/2-Health Policy and Planning/1-Health Promotion International/ 1-International Journal of Health Services/1 - International Journal of Public Health/1_Journal of Advanced Nursing/1_-Journal of Environmental Psychology/1 — Journal of Health Care for the Poor and Underserved/1-Journal of Health Communication/1—Journal of Law, Medicine \& Ethics/1_Journal of Planning Education and Research/1_Journal of Policy Modeling/1—Ocean \& Coastal Management/1-Policy Sciences/1-Revista Panamericana de Salud Pública/1—Saúde e Sociedade/1—Science Communication/1—Social Indicators Research/1—Society \& Natural Resources/1—Transboundary and Emerging Diseases/1.

Elaborated by the authors. 
Table 2. Examples of dialectic approach and means of relation with public policies among selected papers.

$$
\text { Dialectic approach and relation with public policy }
$$

The Nuclear Risk Management for Native Communities (NRMNC) is a collaborative academic, community-based and tribal project which aimed at involving native American people exposed to radiation caused by the U.S. weapon testing in the 1950's and 1960's. The project promoted the participation of stakeholders through technical and educational methodologies about radiation hazards and was induced in 1994 by an Executive Order for Environmental Justice, signed by President Clinton.

In a context of urban social inequities in Northern Ireland a participatory rapid appraisal was proceeded comprising representatives of local community employing tools like focus groups and questionnaire. The initiative lead to a dialogue between social actors and health practitioners around the primary health care policy and revealed some social and environmental factors which were ignored before.

The paper explores how the European Union's wide regulation of chemicals, the REACH system, can be applied to the Austrian context considering the complexity and uncertainties under the cost-benefit analysis. This analysis is multifactorial and its outcomes can subsidize an important dialogue with stakeholders (producer, consumers, employees and policy-makers) who thus will have means to decide what chemicals should be employed or banished even under a precautionary principle.

The Healthy Alberta Communities is a community-university-government partnership held in Canada which involves local representatives in a participatory approach by studying and classifying environment by types making possible that local community stakeholders identify environmental determinants of chronic diseases and obesity, also offering opportunities to influence values, change environments and create a culture supportive of healthy living.

This paper reveals multiple factors that hinder a multilevel governance system under the case of the European directives for safe drinking water. The focus of the study is to explain why some parts of Hungary continue to deliver drinking water that exceeds the directives, considering that there are multiple Leventon \& Antypas, 2012 [25] layers of governance between EU's legislation and the municipalities, and each of them must have a role to play in translating legislation into action.

Elaborated by the authors.

Table 3. Classification of selected papers through territorial scales of intervention.

\begin{tabular}{|c|c|c|}
\hline Local & Expanded & Multilevel \\
\hline (Quigley et al., 2000) [21] & (Millard, 2002) [42] & (Montiel \& Barten, 1999) [45] \\
\hline (Lazenbatt et al., 2001) [22] & (Heiskanen et al., 2009) [30] & (Curtis \& Lockwood, 2000) [46] \\
\hline (Latowsky, 2003) [35] & (D’Alisa et al., 2010) [43] & (Hadi, 2000) [47] \\
\hline (Sanchez et al., 2004) [36] & (Gonzalez et al., 2011) [31] & (Whittington et al., 2000) [48] \\
\hline (Laurian, 2005) [37] & (Allen et al., 2012) [44] & (Berkes et al., 2001) [49] \\
\hline (Schulz \& Northridge, 2004) [28] & & (Moctezuma, 2001) [33] \\
\hline (Wells, 2005) [38] & & (Schroeder et al., 2001) [50] \\
\hline (Plescia et al., 2008) [26] & & (Maantay, 2002) [51] \\
\hline (Postma, 2008) [39] & & (O’Fallon et al., 2003) [52] \\
\hline (Spiegel et al., 2008) [29] & & (Brown et al., 2004) [53] \\
\hline (Keirns, 2009) [40] & & (Sloane et al., 2006) [54] \\
\hline (Raine et al., 2010) [24] & & (van den Hove, 2007) [32] \\
\hline (Kreuter et al., 2012) [41] & & (Getzner, 2008) [23] \\
\hline \multirow[t]{4}{*}{ (Nampanya et al., 2012) [27] } & & (Williams et al., 2008) [55] \\
\hline & & (Freitas Setti \& Bogus, 2010) [56] \\
\hline & & (Cheadle et al., 2011) [57] \\
\hline & & (Leventon \& Antypas, 2012) [25] \\
\hline $\mathrm{N}=14$ & $\mathrm{~N}=5$ & $\mathrm{~N}=17$ \\
\hline
\end{tabular}

Elaborated by the authors. 
der environmental injustice or social exclusion. As the example of native communities exposed to radiation hazards [21] we also have experiences with engagement of community actors to avoid risk factors to heart disease and diabetes though promoting healthy behaviors and environments [26], or participatory research and job training with rural works in Cambodia aiming at avoiding the transmission of transboundary infectious diseases [27]. In summary, the local approaches have focus on stimulating and promoting a high quality of community engagement within distinct phases of research and interventions as the Community-based participatory research demands [12]. Regarding the relation with public policy these papers can bring the perspective of empowerment associated with the principle of advocacy dealing with some public policies [28], but also can be related to means in which social actors assume a role to improve public policies through social control [29].

The extended territorial scale of intervention was represented by five papers which had their approaches limited to a wider than local territory without dealing with further spatial scales. For example, in a national context, Heiskanen et al. (2009) [30] describe how transition management, as a specific design for long-term policy making, aiming at environmental and health issues has been applied in Finland. Also in the extended territorial scale we observe an application in a town with the participation of population representatives and policymakers to increase visibility and to interact with environmental policy concerning urban air pollution in West Oakland, California, USA [31].

The combination of a certain policy through different territorial scales was the key for classifying 17 papers as multilevel territorial approaches. In this sense Van Den Hove (2007) [32] describes a dialect of a worldwide prerogative of the Intergovernmental Panel on Climate Change (IPCC) and the respective developments of the overall European science-policy interface. Moctezuma (2001) [33] describes how community-based mapping allowed better management of natural resources in municipalities in Mexico, and so representing an important role within national political changes. The above cited papers of Getzner (2008) [23] and Leventon \& Antypas (2012) [25] are also examples of multilevel approaches, since both engage through an approach from the context of the European Union to a country.

Van Den Hove (2007) [32] argues that science-policy interfaces are emerging as key elements of environmental governance and Ravetz (2004) [8] emphasizes that a wide participation of society is required to deal with the emerging complexity and stakes that are characteristic of environmental and health problems. In our review, we consider to have reached progress recognizing the importance of cross-territorial analysis to explore differences among dialectic approaches dealing with public policies concerned with socio, environmental and health problems. Indeed, exploring the multilevel interactions makes it possible to reinforce that any isolated public policy is good enough to tackle problems that transcend territorial scales. Frenk \& Moon (2013) [34] claim that the globalization and its consequences, like health effects of climate change and trade policies, represent one of the more important challenges to the governance of global health. In this sense, the trade-offs across territorial scales as well as respective multilevel territory approaches should be considered at the heart of the health promotion movement.

\section{Conclusion}

In conclusion, the selected papers of this bibliographic review allowed us to claim that before the complexity of critical scenarios of environmental injustice a scarce scientific production showed the importance of dialectic approaches to deal with socio, environmental and health questions, though emphasizing the need for considering the interface with public policy across different spatial scales. With this analysis, we highlight that to cope with the driving forces which come from global scale to induce pressures in local scales the multilevel approaches must be strengthened and reproduced aiming at intervening in the causes of the environmental injustice. Moreover, we state that these findings represent current challenges to the combined application of three relevant strategies of the Ottawa Charter for health promotion (WHO, 1986): strengthening of community action, creating supportive environments, and building healthy public policies.

\section{Acknowledgements}

To FAPESP—São Paulo Research Foundation (proc.n.2010/20899-0 and proc.n.2010/13839-0—post-doctorate scholarship of Renata Ferraz de Toledo); and Ricardo Agum Ribeiro thanks the doctoral scholarship provided by CAPES/IMPeTAm. 


\section{References}

[1] Martinez-Allier, J. (2007) O ecologismo dos pobres. Contexto, São Paulo.

[2] Harvey, D. (2009) Condição Pós-Moderna: Uma pesquisa sobre as origens da mudança cultural. 18a Edition, Loyola, São Paulo.

[3] WHO (1986) Ottawa Charter for Health Promotion. WHO, Geneva.

[4] Kickbusch, I. (2003) The Contribution of the World Health Organization to a New Public Health and Health Promotion. American Journal of Public Health, 93, 383-388. http://dx.doi.org/10.2105/AJPH.93.3.383

[5] Prado Jr., C. (1973) Teoria marxista do conhecimento e método dialético materialista. In Discurso-Revista do Departamento de Filosofia da Faculdade de Filosofia, Letras e Ciências Humanas da Universidade de São Paulo, 41-78.

[6] Freire, P. (1987) Pedagogia do oprimido. 17th Edition, Paz e Terra, Rio de Janeiro.

[7] Funtowicz, S. and Ravetz, J.R. (1993) Science for the Post-Normal Age. Futures. London, 25, 739-755. http://dx.doi.org/10.1016/0016-3287(93)90022-L

[8] Ravetz, J. (2004) The Post-Normal Science of Precaution. Futures, 36, 347-357. http://dx.doi.org/10.1016/S0016-3287(03)00160-5

[9] Lebel, J. (2003) Health: An Ecosystem Approach. International Development Research Centre, Ottawa.

[10] Lewin, K. (1946) Action Research and Minority Problems. Journal of Social Issues, 2, 34-46. http://dx.doi.org/10.1111/j.1540-4560.1946.tb02295.x

[11] Carr, W. and Kemmis, S. (1986) Becoming Critical: Education, Knowledge and Action Research. The Palmer Press, London.

[12] Cashman, S.B., Adeky, S., Allen III, A.J., Corbum, J., Israel, B.A., Montaño, J., et al. (2008) The Power and the Promise: Working with Communities to Analyse Data, Interpret Findings, and Get to Outcomes. American Journal of Public Health, 98, 1407-1417. http://dx.doi.org/10.2105/AJPH.2007.113571

[13] Adelman, C. (1993) Kurt Lewin and the Origins of Action Research. Educational Action Research, 1, 7-24. http://dx.doi.org/10.1080/0965079930010102

[14] Wesselink, A. and Hoppe, R. (2011) If Post-Normal Science Is the Solution, What Is the Problem?: The Politics of Activist Environmental Science. Science, Technology, \& Human Values, 36, 389-412.

http://sagepub.com/journalsPermissions.nav http://dx.doi.org/10.1177/0162243910385786

[15] List, D. (2006) Action Research Cycles for Multiple Futures Perspectives. Futures, 38, 673-684. http://dx.doi.org/10.1016/j.futures.2005.10.001

[16] Hancock, T. (2011) The Ottawa Charter at 25. Canadian Journal of Public Health, 102, 404-406.

[17] Kickbush, I. (2007) The Move towards a New Public Health. IUHPE_Promotion \& Educational Suplement, $2,9$.

[18] Liberati, A., et al. (2009) The PRISMA Statement for Reporting Systematica Reviews and Meta-Analyses of Studies That Evaluate Healthcare Interventions: Explanation and Elaboration. British Medical Journal, 339, b2700. http://dx.doi.org/10.1136/bmj.b2700

[19] Jacso, P. (2005) As We May Search-Comparison of Major Features of the Web of Science, Scopus, and Google Scholar Citation-Based and Citation-Enhanced Databases. Current Science, 89, 1537-1547. http://choo.fis.utoronto.ca/FIS/courses/LIS1325/Readings/jacso.pdf.

[20] Kingdon, J. (2003) Agendas, Alternatives and Public Policies. 2nd Edition, Addison-Wesley Educational Publishers Inc., New York, 90-208.

[21] Quigley, D., Handy, D., Goble, R., Sanchez, V. and George, P. (2000) Participatory Research Strategies in Nuclear Risk Management for Native Communities. Journal of Health Communication, 5, 305-331. http://dx.doi.org/10.1080/10810730050199123

[22] Lazenbatt, A., Lynch, U. and O’Neill, E. (2001) Revealing the Hidden “Troubles” in Northern Ireland: The Role of Participatory Rapid Appraisal. Health Education Research, 16, 567-578. http://dx.doi.org/10.1093/her/16.5.567

[23] Getzner, M. (2008) Uncertainties and the Precautionary Principle in Cost-Benefit Environmental Policies. Journal of Policy Modeling, 30, 1-17. http://dx.doi.org/10.1016/j.jpolmod.2007.09.003

[24] Raine, K.D., Plotnikoff, R., Nykiforuk, C., Deegan, H., Hemphill, E., Storey, K. and Ohinmaa, A. (2010) Reflections on Community-Based Population Health Intervention and Evaluation for Obesity and Chronic Disease Prevention: The Healthy Alberta Communities Project. International Journal of Public Health, 55, 679-686. http://dx.doi.org/10.1007/s00038-010-0187-7

[25] Leventon, J. and Antypas, A. (2012) Multi-Level Governance, Multi-Level Deficits: The Case of Drinking Water 
Management in Hungary. Environmental Policy and Governance, 22, 253-267. http://dx.doi.org/10.1002/eet.1590

[26] Plescia, M., Herrick, H. and Chavis, L. (2008) Improving Health Behaviors in an African American Community: The Charlotte Racial and Ethnic Approaches to Community Health Project. American Journal of Public Health, 98, 16781684. http://dx.doi.org/10.2105/AJPH.2007.125062

[27] Nampanya, S., Suon, S., Rast, L. and Windsor, P.A. (2012) Improvement in Smallholder Farmer Knowledge of Cattle Production, Health and Biosecurity in Southern Cambodia between 2008 and 2010. Transboundary and Emerging Diseases, 59, 117-127. http://dx.doi.org/10.1111/j.1865-1682.2011.01247.x

[28] Schulz, A. and Northridge, M.E. (2004) Social Determinants of Health: Implications for Environmental Health Promotion. Health Education \& Behavior, 31, 455-471. http://dx.doi.org/10.1177/1090198104265598

[29] Spiegel, J.M., Gonzalez, M., Cabrera, G.J., Catasus, S., Vidal, C. and Yassi, A. (2008) Promoting Health in Response to Global Tourism Expansion in Cuba. Health Promotion International, 23, 60-69. http://dx.doi.org/10.1093/heapro/dam040

[30] Heiskanen, E., Kivisaari, S., Lovio, R. and Mickwitz, P. (2009) Designed to Travel? Transition Management Encounters Environmental and Innovation policy Histories in Finland. Policy Sciences, 42, 409-427. http://dx.doi.org/10.1007/s11077-009-9094-2

[31] Gonzalez, P.A., Minkler, M., Garcia, A.P., Gordon, M., Garzon, C., Palaniappan, M. and Beveridge, B. (2011) Community-Based Participatory Research and Policy Advocacy to Reduce Diesel Exposure in West Oakland, California. American Journal of Public Health, 101, S166-S175. http://dx.doi.org/10.2105/AJPH.2010.196204

[32] Van den Hove, S. (2007) A Rationale for Science-Policy Interfaces. Futures, 39, 807-826. http://dx.doi.org/10.1016/j.futures.2006.12.004

[33] Moctezuma, P. (2001) Community-Based Organization and Participatory Planning in South-East Mexico City. Environment and Urbanization, 13, 117-133. http://dx.doi.org/10.1177/095624780101300209

[34] Frenk, J. and Moon, S. (2013) Governance Challenges in Global Health. New England Journal of Medicine, 369, 936942. http://dx.doi.org/10.1056/NEJMra1109339

[35] Latowsky, G. (2003) Report: Community-Based, Participatory Research in Lawrence, Massachusetts, Flags Environmental Health Hazards and Fuels Education and Action. Science Communication, 25, 204-208. http://dx.doi.org/10.1177/1075547003259449

[36] Sanchez, L., Perez, D., Cruz, G., Silva, L.C., Boelaert, M. and Van der Stuyft, P. (2004) Community Participation in the Control of Aedes aegypti: Opinions of the Population in One Section of Havana, Cuba. Revista Panamericana de Salud Publica-Pan American Journal of Public Health, 15, 19-25.

[37] Laurian, L. (2005) Public Input in Toxic Site Cleanup Decisions: The Strengths and Limitations of Community Advisory Boards. Environment and Planning B-Planning \& Design, 32, 445-467. http://dx.doi.org/10.1068/b31046

[38] Wells, N.M. (2005) Our Housing, Our Selves: A Longitudinal Investigation of Low-Income Women’s Participatory Housing Experiences. Journal of Environmental Psychology, 25, 189-206. http://dx.doi.org/10.1016/j.jenvp.2005.02.002

[39] Postma, J. (2008) Elucidating Empowerment in El Proyecto Bienestar (the Well-Being Project). Journal of Advanced Nursing, 62, 441-450. http://dx.doi.org/10.1111/j.1365-2648.2008.04605.x

[40] Keirns, C.C. (2009) Asthma Mitigation Strategies: Professional, Charitable, and Community Coalitions. American Journal of Preventive Medicine, 37, S244-S250. http://dx.doi.org/10.1016/j.amepre.2009.08.004

[41] Kreuter, M.W., Kegler, M.C., Joseph, K.T., Redwood, Y.A. and Hooker, M. (2012) The Impact of Implementing Selected CBPR Strategies to Address Disparities in Urban Atlanta: A Retrospective Case Study. Health Education Research, 27, 729-741. http://dx.doi.org/10.1093/her/cys053

[42] Millard, J. (2002) e-Government Strategies: Best Practice Reports from the European Front Line. In: Traumuller, R. and Lenk, K., Eds., Proceedings of the Electronic Government, Lecture Notes in Computer Science, Springer, Berlin, 298-306.

[43] D’Alisa, G., Burgalassi, D., Healy, H. and Walter, M. (2010) Conflict in Campania Waste Emergency or Crisis of Democracy. Ecological Economics, 70, 239-249. http://dx.doi.org/10.1016/j.ecolecon.2010.06.021

[44] Allen, N.E., Javdani, S., Lehrner, A.L. and Walden, A.L. (2012) “Changing the Text”: Modeling Council Capacity to Produce Institutionalized Change. American Journal of Community Psychology, 49, 317-331. http://dx.doi.org/10.1007/s10464-011-9460-z

[45] Montiel, R.P. and Barten, F. (1999) Urban Governance and Health Development in Leon, Nicaragua. Environment and Urbanization, 11, 11-26.

[46] Curtis, A. and Lockwood, M. (2000) Landcare and Catchment Management in Australia: Lessons for State-Sponsored Community Participation. Society \& Natural Resources, 13, 61-73. http://dx.doi.org/10.1080/089419200279243 
[47] Hadi, A. (2000) A Participatory Approach to Sanitation: Experience of Bangladeshi NGOs. Health Policy and Planning, 15, 332-337. http://dx.doi.org/10.1093/heapol/15.3.332

[48] Whittington, D., Davis, J., Miarsono, H. and Pollard, R. (2000) Designing a “Neighborhood Deal” for Urban Sewers: A Case Study of Semarang, Indonesia. Journal of Planning Education and Research, 19, 297-308. http://dx.doi.org/10.1177/0739456X0001900309

[49] Berkes, F., Mathias, J., Kislalioglu, M. and Fast, H. (2001) The Canadian Arctic and the Oceans Act: The Development of Participatory Environmental Research and Management. Ocean \& Coastal Management, 44, 451-469. http://dx.doi.org/10.1016/S0964-5691(01)00060-6

[50] Schroeder, P.C., Boudreau, P.R., Brehme, C.E.W., Boyce, A.M., Evans, A.J. and Rahmani, A. (2001) The Gulf of Maine Environmental Information Exchange: Participation, Observation, Conversation. Environment and Planning B-Planning \& Design, 28, 865-887. http://dx.doi.org/10.1068/b2749t

[51] Maantay, J. (2002) Zoning Law, Health, and Environmental Justice: What's the Connection? Journal of Law Medicine \& Ethics, 30, 572-593. http://dx.doi.org/10.1111/j.1748-720X.2002.tb00427.x

[52] O’Fallon, L.R., Wolfle, G.M., Brown, D., Dearry, A. and Olden, K. (2003) Strategies for Setting a National Research Agenda that Is Responsive to Community Needs. Environmental Health Perspectives, 111, 1855-1860.

[53] Brown, P., Mayer, B., Zavestoski, S., Luebke, T., Mandelbaum, J. and McCormick, S. (2004) Clearing the Air and Breathing Freely: The Health Politics of Air Pollution and Asthma. International Journal of Health Services, 34, 39-63. http://dx.doi.org/10.2190/D7QX-Q3FQ-BJUG-EVHL

[54] Sloane, D., Nascimento, L., Flynn, G., Lewis, L., Guinyard, J.J., Galloway-Gilliam, L. and Yancey, A. (2006) Assessing Resource Environments to Target Prevention Interventions in Community Chronic Disease Control. Journal of Health Care for the Poor and Underserved, 17, 146-158. http://dx.doi.org/10.1353/hpu.2006.0081

[55] Williams, A., Holden, B., Krebs, P., Muhajarine, N., Waygood, K., Randall, J. and Spence, C. (2008) Knowledge Translation Strategies in a Community-University Partnership: Examining Local Quality of Life (QoL). Social Indicators Research, 85, 127-144.

[56] Freitas Setti, A.F. and Bogus, C.M. (2010) Community Participation in an Intervention Program Developed in a Protected Area. Saude e Sociedade, 19, 946-960. http://dx.doi.org/10.1590/S0104-12902010000400020

[57] Cheadle, A., Bourcier, E., Krieger, J., Beery, W., Smyser, M., Vinh, D.V. and Alfonsi, L. (2011) The Impact of a Community-Based Chronic Disease Prevention Initiative: Evaluation Findings from Steps to Health King County. Health Education \& Behavior, 38, 222-230. http://dx.doi.org/10.1177/1090198110371463 